\title{
ANALISIS KESALAHAN EJAAN DALAM SKRIPSI MAHASISWA
}

\author{
Septia Uswatun Hasanah ${ }^{1}$, Dea Putri Utami ${ }^{2}$ \\ Universitas Sang Bumi Ruwa Jurai \\ septiauswatunhasanah@gmail.com ${ }^{1}$,deaputriu@gmail.com ${ }^{2}$
}

\begin{abstract}
Abstrak
Skripsi merupakan suatu karya ilmiah yang berupa tulisan mahasiswa sebagai persyaratan menjadi seorang sarjana. Namun, dalam skripsi terdapat kesalahan-kesalahan dalam penulisan tanpa disadari. Kesalahan penulisan ini sendiri berdampak pada makna yang akan disampaikan. Minimnya pengetahuan tentang ejaan mengakibatkan banyak sekali penulis masih melakukan kesalahan dalam penulisannya. Dari beberapa masalah yang ada pada ejaan peneliti merasa penting untuk meneliti kesalahan ejaan dalam skripsi mahasiswa. Tujuan penelitian ini untuk mendeskripsikan kesalahan penulisan pada huruf kapital, huruf miring, tanda baca, dan kata depan. Penelitian ini menggunakan desain deskirptif kualitatif. Teknik pengumpulan data dalam penelitian ini menggunakan teknik baca, kemudian teknik catat dengan menggolongkan sesuai dengan kesalahan ejaan, setelah itu baru dianalisis kesalahan-kesalahan ejaan yang sudah didapat. Hasil dari penelitian ini ditemukan kesalahan dalam penulisan ejaan huruf kapital 95, huruf miring 56, kata depan 74, dan tanda baca 121. Dari beberapa kesalahan yang terjadi didominasikan pada penulisan tanda baca sebab mahasiswa kurang memahami bagaimana penggunaan tanda koma setelah kata hubung dan tanda koma dalam kalimat.
\end{abstract}

Kata Kunci: Analisis, kesalahan ejaan, skripsi mahasiswa

\begin{abstract}
Thesis is a scientific work in the form of student writing as a requirement to become a scholar. However, in the thesis there are errors in writing without realizing it. This writing error itself has an impact on the meaning to be conveyed. The lack of knowledge about spelling resulted in many writers making mistakes in writing. Of the several problems that exist in spelling, the researcher feels it is important to examine spelling errors in student theses. The purpose of this study was to describe the writing errors in capital letters, italics, punctuation, and prepositions. This study used a qualitative descriptive design. The data collection technique in this study used the reading technique, then the notetaking technique was classified according to the spelling errors, after which the spelling errors that had been obtained were analyzed.The results of this study found errors in the writing of capital letters 95, 56 italics, 74 prepositions, and 121 punctuation marks. Of the several errors that occurred were dominated in writing punctuation because students did not understand how to use a comma after a hyphen and comma in sentences.
\end{abstract}

Keywords: Analysis, spelling errors, student thesis

\section{PENDAHULUAN}

Kesalahan-kesalahan ejaan dalam penulisan merupakan kesalahan yang banyak terjadi baik itu disadari maupun tidak disadari. Kesalahan penulisan ini sendiri berdampak pada makna yang akan disampaikan. Minimnya pengetahuan tentang ejaan mengakibatkan banyak sekali penulis masih melakukan kesalahan dalam penulisannya.

Skripsi merupakan suatu karya ilmiah yang berupa tulisan mahasiswa sebagai persyaratan menjadi seorang sarjana. Skripsi disusun dengan mengacu pada karya tulis mahasiswa yang penyusunannya didasarkan pada kajian ilmiah dan tentunya harus memakai bahasa Indonesia sesuai dengan ejaan PUEBI (Pedoman Umum Ejaan Bahasa Indonesia). 
Untuk mendapatkan hasil penelitian yang baik dari segi bahasa tentunya mahasiswa harus mempunyai ilmu dalam bidang bahasa khususnya pada ejaan. Oleh karena itu, mahasiswa yang menulis skripsi harus menggunakan ejaan yang benar sesuai PUEBI dan KBBI.

Dari hasil observasi peneliti membaca skripsi mahasiswa ternyata masih banyak mahasiswa yang kurang mampu menggunakan bahasa Indonesia sesuai dengan kaidah-kaidah penulisan karya ilmiah. Berdasarkan observasi tersebut, mata kuliah bahasa Indonesia sangat penting pada tingkat perguruan tinggi.

Dengan adanya masalah di atas peneliti ingin melakukan penelitian tentang bagaimana penulisan kata depan, penulisan tanda baca, huruf kapital, dan huruf miring dalam penulisan skripsi mahasiswa. Berdasarkan uraian di atas peneliti menganggap penting untuk melakukan penelitian mengenai "Analisis Kesalahan Ejaan dalam Skripsi Mahasiswa”.

Penelitian sebelumnya mengenai kesalahan ejaan yang berjudul "Analisis Kesalahan Ejaan pada Karya Ilmiah Mahasiswa Bahasa Indonesia Stkip Bina Bangsa Getsempena Banda Aceh" yang ditulis oleh Rika Kustina dan diterbitkan oleh jurnal ilmiah Jurnal Metamorfosa Volume 6, No. 1 2018. Dengan hasil yang didapat dalam penelitian tersebut menganalisis beberapa kesalahan yang terdapat pada skripsi yaitu kesalahan penggunaan huruf kapital, kesalahan penggunaan huruf miring, dan penggunaan huruf tebal.

\section{METODE PENELITIAN}

Rancangan pada dasarnya merupakan keseluruhan proses pemikiran dan penentuan matang tentang hal-hal yang akan dilakukan (Margono, 2010: 100). Rancangan penelitian (desain) ini menggunakan penelitian kualitatif deskriptif yaitu data yang dikumpulkan adalah berupa kata-kata, gambar, dan bukan angka-angka

Penelitian ini dilakukan mulai dari Juli sampai dengan Oktober 2020 di Universitas Sang Bumi Ruwa Jurai dan menggunakan data Perpustakaan Universitas Sang Bumi Ruwa Jurai.

Sumber data dalam penelitian ini adalah skripsi mahasiswa Universitas Sang Bumi Ruwa Jurai Tahun 2019 yang berjumlah 288 skripsi dari empat fakultas, yaitu 137 skripsi dari Fakultas Ekonomi, 65 skripsi dari Fakultas Hukum, 45 skripsi dari Fakultas Teknik, dan 41 skripsi dari Fakultas Fisipol.

Sampel didefinisikan sebagai bagian dari populasi yang merupakan wakil-wakil yang representatif dari suatu populasi tersebut (Suharsimi Arikunto, 2012: 117). Menurut Arikunto (2012: 116) "Apabila kurang dari 100 lebih baik diambil semua hingga penelitiannya merupakan penelitian populasi. Jika jumlah subjeknya lebih dari 100 dapat diambil antara 10-15\% atau 2055\% atau lebih". Populasi yang ada sebanyak 288 skripsi, peneliti mengambil 10\% dari 288 skripsi. Dengan demikian responden yang dapat dijadikan sampel dalam penelitian ini adalah sebanyak 29 responden yang berupa skripsi mahasiswa.

\section{HASIL DAN PEMBAHASAN}

\section{Hasil Penelitian}

Setelah peneliti melakukan penelitian dari berbagai skripsi mahasiswa tahun 2019 mendapatkan bebebrapa kesalahan dalam penulisan ejaan. Temuan hasil peneliti sebagai berikut:

\begin{tabular}{lll}
\hline No. & Jenis Kesalahan & Jumlah Kesalahan \\
\hline 1. & Huruf Kapital & 95 \\
\hline 2. & Huruf Miring & 56 \\
\hline 3. & Kata Depan & 74 \\
\hline
\end{tabular}




\begin{tabular}{lll}
\hline 4. & Tanda Titik & 48 \\
\hline $\mathbf{5 .}$ & Tanda Koma & 68 \\
\hline 6. & Tanda Hubung & 5 \\
\hline Jumlah & 346 \\
\hline
\end{tabular}

\section{Pembahasan}

Kesalahan Penulisan Huruf Kapital

\section{Data}

Pengaruh Budaya Organisasi Terhadap Kinerja Pegawai Dinas Perhubungan, Komunikasi, dan Informatika Kabupaten Pesisir Barat. (R, 2019: 6)

Penulisan judul di atas terdapat kesalahan pada pemakaian huruf kapital. Penulisan judul setiap kata diawali dengan huruf kapital kecuali kata tugas atau kata hubung. Contohnya di atas menggunakan kata terhadap yang seharusnya tidak diberikan huruf kapital.

\section{Data}

....lingkungan kerja yang kurang baik dapat melemahkan Motivasi pegawai yang berdampak pada lemahnya kinerja pegawai. Dalam hal ini Motivasi yang tinggi sangat dibutuhkan untuk mencapai tujuan organisasi, karena dengan adanya Motivasi dalam diri pegawai...(H, 2019: 1).

Data di atas yang digarisbawahi terdapat beberapa kesalahan dalam menggunakan huruf kapital yang seharusnya tidak perlu memakai huruf kapital. Setiap kata motivasi di atas penggunaan huruf kapital tidak sesuai dengan kaidah bahasa Indonesia sebab kata motivasi di atas bukan awal kalimat, judul atau nama orang.

\section{Data}

Melaksanakan Standar, normal, Pedoman, Kriteria, dan Prosedur Pembimbing Warga Binaan Permasyarakatan. (A, 2019: 37)

Kalimat di atas terdapat beberapa penggunaan huruf kapital yang tidak tepat. Kata-kata pada kalimat yang digarisbawahi tersebut seharusnya tidak menggunakan huruf kapital cukup pada kata pertama pada kalimat yang menggunakan huruf kapital sebab kalimat di atas bukan berupa judul yang setiap kata harus diberikan huruf kapital.

\section{Data}

...empat unit dan satu buah mobil dinas tua Fasilitas transportasi tersebut kurang memenuhi syarat guna menempuh wilayah kerja yang cukup jauh dengan medan yang cukup berat...(A, 2019: 46)

Data di atas terdapat huruf kapital di tengah kalimat yang seharusnya tidak diberikan huruf kapital pada kata yang digarisbawahi sebab kata tersebut tidak juga di awal kalimat yang seharusnya diberikan huruf kapital.

\section{Data}

b. untuk memperoleh data dan fakta mengenai Faktor Penghambat Dalam Penegakkan Disiplin Anggota POLRI.

Kalimat di atas merupakan salah satu tujuan penelitian yang terdapat kesalahan pada penulisan huruf kapital. Kata yang digarisbawahi seharusnya tidak perlu diberikan huruf kapital sebab tidak termasuk kategori kata yang harus diberikan huruf Kapital di dalam tata penulisan secara PUEBI.

\section{Data}

"setiap orang berhak atas pengakuan, jaminan, perlindungan dan kepastian hukum yang adil serta perlakuan yang sama di hadapan hukum”. (S, 2019:1) 
Pada data di atas terdapat kesalahan penulisan huruf kapital. Kata "Setiap" seharusnya menggunkana huruf kapital pada huruf pertama sebab setiap setelah tanda kutip kata pertama harus menggunakan huruf kapital di awal kalimat. Jadi, kalimat di atas bila ditulis dengan benar "Setiap orang berhak atas pengakuan, jaminan, perlindungan dan kepastian hukum yang adil serta perlakuan yang sama di hadapan hukum".

\section{Data}

Berdasarkan latar belakang di atas, maka peneliti tertarik untuk melakukan penelitian dengan judul Dampak Kebijakan Perizinan Tambak Udang Terhadap Pengelolaan Lingkungan Hidup di Pekon Sukarame Kecamatan Ngaras Kabupaten Pesisir Barat (G, 2019: 5)

Kalimat di atas terdapat kesalahan dalam penulisan judul yang menggunakan huruf kapital. Pada kata yang digarisbawahi tersbut merupakan salah satu kata tugas yang seharusnya dalam penulisan judul tidak diberikan huruf kapital. Jadi, penulisan judul di atas yang benar "Dampak Kebijakan Perizinan Tambak Udang terhadap Pengelolaan Lingkungan Hidup di Pekon Sukarame Kecamatan Ngaras Kabupaten Pesisir Barat"

\section{Kesalahan Penulisan Huruf Miring}

\section{Data}

Social study tersebut menerangkan tentang pribadi klien pemasyarakatan yang sidang perkaranya dengan perjanjian atau penyerahan kepada pemerintah untuk mendidik. (A, 2019: 37)

Pada kalimat di atas yang digarisbawahi menggunakan kata bahasa Ingris namun kata tersebut tidak ditulis miring sedangkan dalam kaidah bahasa Indonesia dalam penulisan karya ilmiah setiap kata yang berbahasa asing harus ditulis menggunakan huruf miring.

\section{Data}

Pertanggungjawaban pidana jika diartikan Pound adalah sebagai suatu kewajiban untuk membayar pembalasan yang akan di terima pelaku dari seorang yang telah di rugikan. (S, 2019: 13)

Kalimat di atas terdapat kesalahan dalam penulisan kata "pound" yang seharusnya ditulis dengan huruf miring sebab kata tersebut merupaka kata asing yang harus ditulis dengan huruf miring sesuai dengan aturan dari kaidah bahasa Indonesia.

\section{Data}

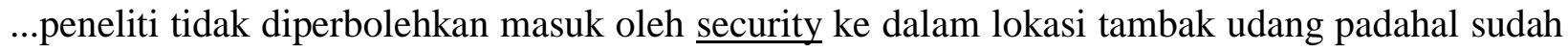
mendapatkan izin...(G, 2019:4)

Data di atas terdapat kesalahan dalam penulisan kata asing yang seharusnya ditulis menggunakan huruf miring. Jadi, jika kalimat di atas diperbaiki akan menjadi “...peneliti tidak diperbolehkan masuk oleh security ke dalam lokasi tambak udang padahal sudah mendapatkan izin..."

\section{Kesalahan Penulisan Kata depan}

\section{Data}

Bahwa dalam kehidupan sehari-hari, seorang anggota Polri di tuntut melakukan pengayoman terhadap masyarakat dan pelayanan terhadap masyarakat,...(I, 2019:41)

Data di atas terdapat kesalahan penulisan pada kata depan yang seharus kata yang digarisbawahi tersebut merupakan kata awalan "di-“" bukan merupakan kata depan "di" sehingga penulisan kata di tuntut seharusnya digabung tidak diberikan spasi. 
Seminar Nasional Penelitian dan Pengabdian kepada Masyarakat Universitas Sang Bumi Ruwa Jurai Tahun 2020

\section{Data}

...tindak pidana pada lingkup anggota POLRI dapat di tempuh melalui Hukum disiplin anggota POLRI yang akan di selesaikan melalui: (I, 2019: 45)

Data di atas terdapat 2 kesalahan penulisan kata awalan yang ditulis menjadi kata depan oleh penulis. Kata yang digarisbawahi "di tempuh dan di selesaikan" seharusnya ditulis tidak terpisah seperti, "ditempuh dan diselesaikan" sebab 2 kata tersebut bukan kata depan yang menyatakan tempat.

\section{Data}

Jika dalam peradilan Umum yang berhak menjadi penyidik adalah anggota kepolisian Republik Indonesia atau Pegawai Negeri Sipil tertentu yang diberi wewenang Khusus oleh Undang-undang sebagai mana di atur...(I, 2019: 46)

Kalimat di atas terdapat kesalahan dalam penulisan kata awalan di- yang ditulis menjadi kata depan "di". Kata "di atur" seharusnya ditulis tidak terpisah sehingga penulisannya tepat sesuai dengan kaidah bahasa Indonesia.

\section{Data}

Pertanggunngjawaban pidana adalah sebagai suatu kewajiban untuk membayar pembalasan yang akan diterima pelaku dari seseorang yang telah di rugikan,...(S, 2019: 8)

Pada data di atas terdapat kalimat kesalahan penulisan kata yang digarisbawahi "di rugikan" kata tersebut ditulis terpisah seperti penulisan kata depan di. Namun, kata tersebut merupakan kata kerja yang seharusnya dalam penulisannya tidak terpisah. Jadi, kalimat di atas jika diperbaiki "Pertanggunngjawaban pidana adalah sebagai suatu kewajiban untuk membayar pembalasan yang akan diterima pelaku dari seseorang yang telah dirugikan..." maka kata "di rugikan" harus ditulis "dirugikan".

\section{Data}

Dampak secara sederhana dapat di artikan adalah suatu perubahan yang terjadi akibat suatu aktivitas. (G, 2019: 7)

Kalimat di atas terdapat kekeliruan pada penulisan kata depan dan kata awalan. Kata yang digarisbawahi merupakan sebuah kata kerja yang seharusnya penulisan kata "di artikan" tidak terpisah sebab kata tersebut bukan kata yang menunjukkan tempat atau bukan kata depan di.

\section{Kesalahan Penulisan Tanda Baca}

\section{Data}

Mazhab ini dipelopori A. Lacassagne. dalam teori sebab-sebab terjadinya tindak pidana yang mendasarkan diri pada pemikiran...(S, 2019: 15)

Pada kalimat di atas terdapat kesalahan pada penulisan tanda titik setelah nama yang seharusnya tidak diberikan tanda titik sebab pembeberian tanda titik setelah nama diberikan jika menggunaan nama gelar. Jadi, pada kalimat di atas tanda titik setelah nama harus ditiadakan.

\section{Data}

...menyatakan terdakwa Koko Mancini, SH. anak dari Zubel Lumbanbatu terbukti secara sah dan meyakinkan bersalah melakukan tindak pidana "penggelapan”...)S, 2019:28)

Pada kata yang digarisbawahi merupakan kata yang mengalami kesalahan dalam penulisan nama gelar yang dalam buku panduan ejaan dalam penulisan nama gelar harus diberikan tanda titik seperti, Koko Mancini, S.H. 
Seminar Nasional Penelitian dan Pengabdian kepada Masyarakat Universitas Sang Bumi Ruwa Jurai Tahun 2020

\section{Data}

...menurut masyarakat yang disampaikan badan pengelolaan lingkungan hidup Pesisir Barat bahwa keberadaan tambak udang yang ada tidak sesuai dengan fakta yang ada. Karena lahan yang dibangun tambak sekitar 20 hektar itu adalah lahan masyarakat...(G, 2019:2)

Data di atas mengalami kesalahan pada tanda baca titik yang tidak tepat pada kalimat tersebut. Setelah dibaca seharusnya tanda titik tersebut dihilangkan sebab kalimat berikutnya masih dalam satuan kalimat sebelumnya dan setelah tanda titik tersebut terdapat kata "karena" di dalam buku PUEBI kata karena tidak boleh diberikan tanda titik setelah atau sesudanya sebab kata "karena" merupaka kata hubung di tengah kalimat bukan kata hubung untuk awal kalimat.

\section{Data}

Akses jalan untuk orang yang mempunyai lahan di dalam tambak udang dipersulit. Sedangkan manfaat industrilisasi tambak udang terhadap masyarakat yang ada di Pekon Sukarame...(G, 2019: 4)

Kalimat di atas terdapat kesalahan penggunaan tanda titik yang tidak tepat pada penggunaannya. Sebelum kata "sedangkan" terdapat tanda titik yang seharusnya diberikan tanda koma sebab kalimat tersebut masih dalam kesatuan kalimat dan kata sedangkan bukan kata hubung untuk awal kalimat melainkan kata hubung di tengah kalimat dan sebelum kata sedangkan harus diberikan tanda koma.

\section{Data}

Fenomena ini tampaknya tetap akan menjadi siklus yang abadi dalam tubuh Polri, Komitmen profesionalisme, transparan dan akuntabilitasi......(K, 2019: 2)

Pada kata yang digarisbawahi di atas terdapat kesalahan penulisan yaitu tidak memberikan tanda koma sebelum kata "dan". Setiap perincian lebih dari 2 maka sebelum kata dan harus diberikan tanda koma sesuai dengan kaidah bahasa Indonesia.

\section{Data}

......dengan kualitas kinerja para anggotanya, sehingga organisasi dituntut ......(R, 2019:1)

Kesalahan penulisan kata penghubung sehingga seharusnya tidak diberikan tanda koma. Ada beberapa kata hubung yang memang diberikan tanda koma sebelum kata hubung tapi tidak untuk kata sehingga.

\section{Data}

Dengan demikian budaya organisasi yang merupakan gambaran persepsi...(R, 2019: 1)

Kalimat di atas memakai kata penghubung di awal kalimat yang seharusnya diberikan tanda koma setelah kata penghubung tersebut.

\section{Data}

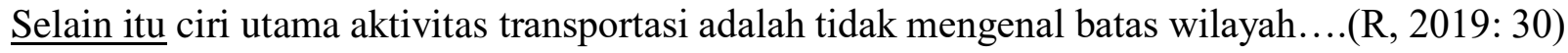

Kesalahan kalimat di atas menggunakan kata penghubung di awal kalimat yang seharusnya diberikan tanda koma setetelah kata hubung selain itu.

\section{Data}

Secara konseptual anggota kepolisian adalah sumber daya manusia organisasi, yang perlu mendapatkan perhatian. (K, 2019:2) 
Seminar Nasional Penelitian dan Pengabdian kepada Masyarakat Universitas Sang Bumi Ruwa Jurai Tahun 2020

Kalimat di atas terdapat kesalahan dalam menggunakan tanda koma yang seharusnya sebelum kata hubung "yang" tidak boleh diberikan tanda koma. Jadi, tanda koma sebelum kata "yang" harus dihilangkan agar sesuai dengan kaidah bahasa Indonesia.

\section{Data}

Tahapan-tahapan tersebut di atas hampir sama dengan tahapan penyelesaian pidana di Peradilan Umum, hanya saja aparat yang berwenang untuk menyelesaikan Perkara, yang berbeda. (I, 2019: 46)

Kalimat di atas yang digarisbawahi terdapat kesalahan penulisan tanda koma yang tidak tepat pada tempatnya. Tanda koma yang diberikan sebelum kata hubung tidak tepat sebab kata hubung "hanya dan yang" seharusnya tidak diberikan tanda koma sebelum atau sesudah kata yang mengikutinya.

\section{Data}

Objektifnya meliputi perbuatan memiliki, suatu benda, yang sebagian atau seluruhnya milik orang lain, yang berada dalam kekuasaannya bukan karena kejahatan....(S, 2019: 30)

Pada di atas terdapat beberapa tanda koma yang kurang tepat penggunaannya. Kata yang digarisbawahi merupakan kata yang terdapat kesalahan dalam penulisan tanda koma yang seharusnya tidak perlu menggunakan tanda koma sebab dalam kalimat tersebut masih dalam 1 induk kalimat dan bukan juga merupakan sebuah perincian dalam kalimat tersebut. Jadi tanda koma yang digarisbawahi seharusnya dihilangkan dalam kalimat tersebut sehingga menjadi kalimat yang lebih efektif.

\section{Data}

Oleh sebab itu diperlukan pengelolaan sum-berdaya alam yang baik dan bijaksana. (G, 2019: 1)

Kalimat di atas terdapat kata hubung yang tidak diberikan tanda koma yang seharusnya jika mengikuti buku ejaan PUEBI kata hubung "oleh karena itu" termasuk kata hubung yang harus diberikan tanda koma setelah kata tersebut. Jadi kesalahan penulis tidak memberikan tanda koma setelah kata hubung "oleh karena itu" jika kalimat di atas perbaiki menjadi "Oleh sebab itu, diperlukan pengelolaan sum-berdaya alam yang baik dan bijaksana."

\section{Data}

Pada dinas daerah dapat dibentuk Unit Pelaksana Teknis Dinas (UPTD) berdasarkan kebutuhan dan bebab kerja; (R, 2019: 43)

Pada kalimat di atas bermaksud memberikan perincian atau penjelasan setelah di akhir kalimat namun, pada akhir kalimat diberikan tanda baca titik koma (;) yang seharusnya untuk memberikan perincian diberikan tanda titik dua (:).

\section{Data}

Oleh sebab itu diperlukan pengelolaan sum-berdaya alam yang baik dan bijaksana. Antara ling-

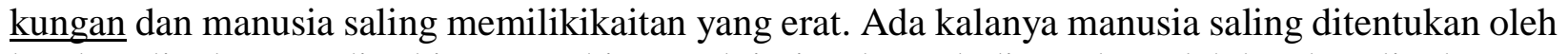
keadaan lingkungan di sekitarnya sehingga akti-vitas banyak ditentukan oleh keadaan lingkungan di sekitarnya. (G, 2019: 1)

Kalimat di atas terdapat kesalahan dalam penggunaan tanda hubung (-) dengan cara memenggal kata namun kata tersebut tidak mengalami pergantian baris sehingga penggunakan tanda hubung tersebut tidak tepat pada penggunaannya.

\section{KESIMPULAN}


Seminar Nasional Penelitian dan Pengabdian kepada Masyarakat Universitas Sang Bumi Ruwa Jurai Tahun 2020

Berdasarkan hasil penelitian dapat disimpulkan sebagai berikut:

1. Kesalahan pada penulisan huruf kapital dalam penulisan skripsi mahasiswa ditemukan sebanyak 95 kesalahan yang meliputi kesalahan pada penulisan judul, awal kalimat, dan di tengah kalimat terdapat huruf kapital. Kesalahan penulisan tersebut diduga kurangnya pemahaman dalam penulisan yang sesua dengan kaidah bahasa Indonesia.

2. Kesalahan pada penulisan huruf miring juga sering terjadi pada penulisan skripsi mahasiswa. Kesalahan penulisan huruf miring ditemukan sebanyak 56 kesalahan. Kesalahan yang sering terjadi pada penulisan huruf miring skripsi mahasiswa adalahah penulisan bahasa asing yang tidak ditulis huruf miring.

3. Kesalahan pada penulisan kata depan dalam penulisan skripsi mahasiswa ditemukan sebanyak 74 kesalahan. Penulisan kata depan sering terjadi kesalahan pada kata depan di, ke- tidak diberikan spasi atau kata awalan ditulis menjadi kata depan. Kesalahan ini terjadi kurangnya pemahaman mengenai perbedaan antara kata depan dan kata awalan.

4. Kesalahan tanda baca dalam penulisan skripsi mahasiswa sering terjadi pada tanda titik (.), koma (,) titik dua (:), tintik koma (;), dan tanda hubung (-). Kesalahan tanda baca ditemukan sebanyak 121 kesalahan diantarnya, 48 kesalahaan penggunaan tanda titik, 68 kesalahan penggunaan tanda koma, dan 5 kesalahan tanda hubung.

\section{DAFTAR PUSTAKA}

Arikunto, Suharsimi. (2012). Prosedur Penelitian Suatu Pendekatan Praktek. Jakarta: Penerbit Bina Marga

Departemen Pendidikan Indonesia. (2008). Kamus Besar Bahasa Indonesia. Jakarta: Balai Pustaka

Gantamitreka. (2016). Kesalahan Berbahasa Penggunaan EYD.Solo:Genta Smart Publisher

Kustina, Rika. (2018). Analisis Kesalahan Ejaan Pada Karya Ilmiah Mahasiswa Bahasa Indonesia Stkip Bina Bangsa Getsempena Banda Aceh. Jurnal Metamorfosa. Lembaga penerbit program studi PBSID STKIP Bina Bangsa Getsempena Banda Aceh.

Margono, S. (2010). Metodologi Penelitian Pendidikan. Jakarta: Rineka Cipta

Setyawati, Nanik. (2010). Analisis Kesalahan Berbahasa Indonesia: Teori dan Praktik. Surakarta: Yuma Pustaka

Sudaryanto. (1992). Metode Linguistik. Yogyakarta: Gajah Mada University Press 